Volume 8, No.3, May - June 2019

International Journal of Advanced Trends in Computer Science and Engineering

Available Online at http://www.warse.org/IJATCSE/static/pdf/file/ijatcse36832019.pdf

https://doi.org/10.30534/ijatcse/2019/36832019

\title{
Intelligent Shortlisting Process for Job Applicants Using Fuzzy Logic-Based Profiling
}

\author{
Caryl Charlene Escolar-Jimenez, DBA ${ }^{1}$, Kichie Matsuzaki, $\mathbf{P h D}^{2}$, \\ and Reggie C. Gustilo, $\mathrm{PhD}^{3}$ \\ ${ }^{1}$ Tokyo City University, Japan, caryl@ tcu.ac.jp \\ ${ }^{2}$ Tokyo City University, Japan, matsuzak@tcu.ac.jp \\ ${ }^{3}$ De La Salle University, Philippines, reggie.gustilo@dlsu.edu.ph
}

\begin{abstract}
A modified version of shortlisting algorithm is presented to improve the selection process of hiring skilled and competent individuals. This algorithm uses fuzzy logic to quantify the educational background and alignment of the applicants as well as their skills and experience. The proposed algorithm shows added flexibility to the human resource managers to choose between the educational background and work experience of a candidate. Two significant numerical outputs are given by the proposed fuzzy inference system namely the Highly Educated Area and the Highly Skilled Area. This scheme enables the company to include the educational alignment of the applicant with respect to the position applied for, and the work experience he had in his previous employments. This intelligent system predicts and filters mechanisms to measure a candidate's alignment to a specific job post, predicting their possible future performance by ranking each individual candidate in real time. This creates a more equitable hiring and selection process for organizations as it determines the best fit candidates according to its needs.
\end{abstract}

Key words: Artificial intelligence, Fuzzy logic, HR analytics, Management, Recruitment, Shortlisting

\section{INTRODUCTION}

Employee recruitment is a core function of human resource management that relates to the planning of the overall organizational strategy and executing concrete measures to attract qualified employees with effective selection methods. Distinguishing the most qualified employee has become more complex as most selection processes utilizes both experimental and statistical techniques that generally has individual biases and stereotypes that is dependent on the interpretation of the job specifications during the selection phase.

As organizations shift to contemporary applications of technology or artificial intelligence platforms to exhaust solutions with the challenging task of applicant shortlisting in the hiring and selection process, these powerful techniques such as fuzzy logic algorithms minimize subjective judgement in the process to disregard irrelevant or redundant features [1] when distinguishing between an appropriate and inappropriate employee for a particular job position [2]. These intelligent methods will identify significant features given a similarity measurement for data analysis [3] that is pertinent to talent acquisition in organizations.

This article is part of the complimentary HR analytics framework research series of the authors in Figure 1 that addresses the gap in the previous shortlisting research in the hiring and selection stage in HRM. Additionally, this article on profiling job applicants will align and determine the relevance of the variables of educational attainment, professional qualifications and training and competencies that is tunable to the preferential needs of both the acquiring department and of the HR.

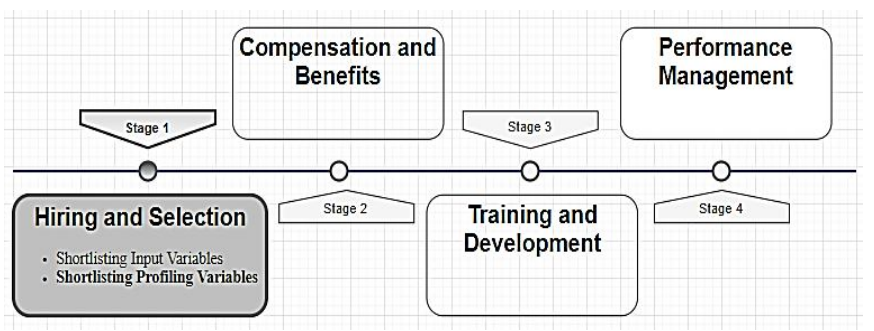

Figure 1: HR Analytics Functional Area Framework

Fuzzy logic is a powerful problem methodology that captures the way humans represent and reason with real-world knowledge in the face of uncertainty [4]. Managers now understand data in a business viewpoint as exact prediction [5] provides pertinent insights for decision making. Therefore, this intelligent algorithm is integral especially in the talent acquisition process in HRM where the shortlist function is derived from a large applicant pool with different skill sets and backgrounds [6].

This algorithm systematizes the complexity of the recruitment process by assigning variables accordingly to the preferential hierarchical criteria and generating appropriate decisions that are also reflective with the specific objectives of the firm. 


\section{PROBLEM STATEMENT}

In an ideal setting, the basis for the final ranking of applicants will be a balanced output in the overall shortlist score in the variables of education and work experience. However, organizations have different labor force requirements depending on the organizational nature and changes in the labor market needs. Therefore, the final output of this fuzzy inference system in Figure 2 clearly identifies relevant applicant variables in the educational attainment, professional qualifications and training and competency in the first level of the recruitment process that coincides with the existing organizational conditions and intelligently profiles qualified applicants that is work specific and aligned to the needs of the firm.

This straightforward approach will enable talent acquisition managers to be proactive strategic thinkers in the hiring process to minimize or totally eliminate human error [7] that assists in building better employer-employee relationships by determining quality hires that are culturally a "good" fit [8] to the organization.

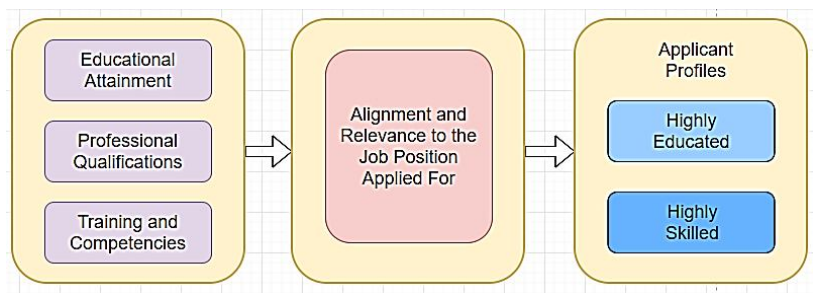

Figure 2: Overview of the Proposed Applicant Profiling System

\section{METHODOLOGY}

The proposed applicant profiling system will be divided into two areas namely the Highly Educated and Highly Skilled. The fuzzy logic structures for the two areas are explained below.

\subsection{Fuzzy Logic Inference System for Highly Educated Area Rating}

This section thoroughly explains the fuzzy logic algorithm that will assign an appraisal or rating score for the profile under the highly educated area.

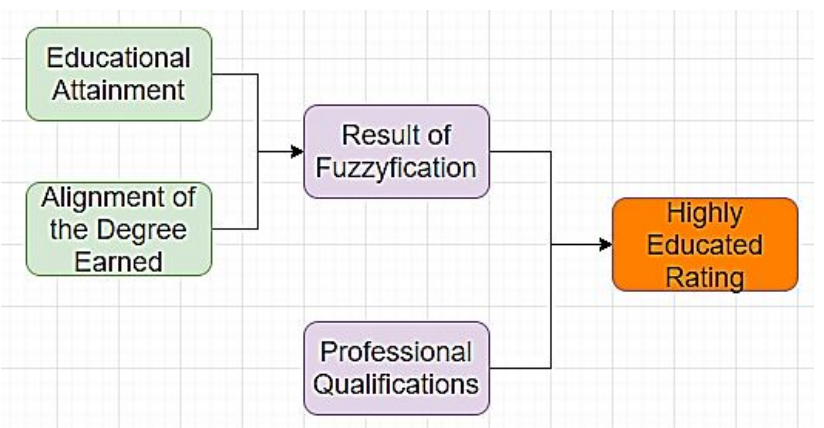

Figure 3: Highly Educated Fuzzy Logic Rating Structure
Figure 3 illustrates the fuzzy logic rating structure in the highly educated area that properly assigns both the applicant's educational attainment and alignment of the degree earned by the employee according to the job availability. This is highly significant as there are organizations who prefer to recruit applicants who are aligned to the available job position to avoid additional employee training and development cost for those working in positions or fields that they are not familiar with.

However, if the organization would favor the concept of the diversity of thought and the degree alignment is not an essential part in the job requirement meaning any degree can be considered for the job, then the fuzzy logic structure for the highly educated area will be reduced based on the structure shown in Figure 4.

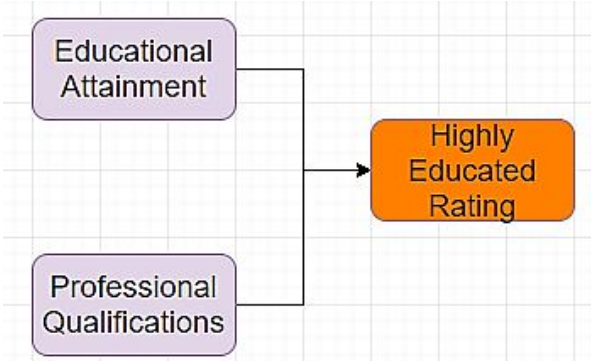

Figure 4: Reduced Fuzzy Logic Structure for Highly Educated Rating

There are also instances that a company prefers alignment in the educational attainment and is not looking for professional license or certification.

Figure 5 below shows the membership function for the educational attainment. Scores shown on the $\mathrm{x}$-axis are used to quantify the applicant's educational attainment.

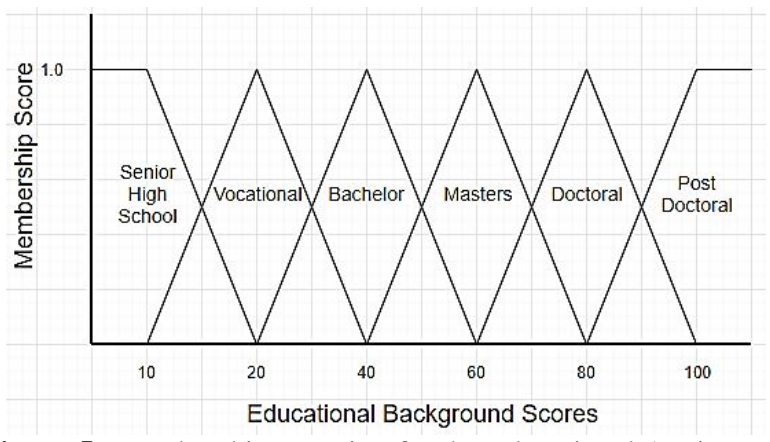

Figure 5: Membership Function for the Educational Attainment

Table 1 below is the proposed scoring system to quantify the educational background of the applicant. This scoring system is very important to quantify or to give numerical values for the highly educated area. This scoring system can then be used to rank applicants according to their educational background. 
Table 1: Score Reference for the Educational Background of the Applicant

\begin{tabular}{|c|c|c|}
\hline Educational Background & Score & Details \\
\hline $\begin{array}{c}\text { Senior High School } \\
\text { Graduate }\end{array}$ & 10 & Minimum Acceptable Educational Attainment \\
\hline \multirow{2}{*}{ Vocational } & $11-19$ & 1point for every month attendance in the course \\
\cline { 2 - 3 } Bachelor & 20 & Finished the vocational course \\
\cline { 2 - 3 } & $21-39$ & 1 point for every 5 units gained in the bachelor's course \\
\hline \multirow{2}{*}{ Master } & 40 & Completed the bachelor's degree \\
\cline { 2 - 3 } Doctoral & $61-59$ & 1 point for every unit gained in the master's course \\
\hline \multirow{2}{*}{ Post-Doctoral } & $61-79$ & Completed the master's degree \\
\cline { 2 - 3 } & 80 & 2 point for every unit gained in the doctor's course \\
\hline & 100 & Completed the doctor's degree \\
\hline
\end{tabular}

Table 2: Score Reference for the Alignment of Educational Background of the Applicant to the Applied Position

\begin{tabular}{|c|c|c|c|}
\hline $\begin{array}{c}\text { Educational } \\
\text { Background } \\
\text { Alignment }\end{array}$ & Score & Details & $\begin{array}{c}\text { Job Grade Points for } \\
\text { Compensation Once } \\
\text { Hired }\end{array}$ \\
\hline Poorly Aligned & 0 & $\begin{array}{c}\text { The educational background of the applicant is } \\
\text { totally misaligned to the applied position }\end{array}$ & 0 \\
\hline $\begin{array}{c}\text { Moderately } \\
\text { Aligned }\end{array}$ & $1-29$ & $\begin{array}{c}\text { The educational attainment from the bachelor's } \\
\text { degree and below are misaligned, but the } \\
\text { applicant continued higher education aligned to } \\
\text { the position. 5 points for every unit earned. }\end{array}$ & $1-9$ \\
\cline { 2 - 5 } & 50 & $\begin{array}{c}\text { The applicant has a bachelor's degree that is } \\
\text { aligned to the applied position. } \\
\text { The applicant has a bachelor's degree that is not } \\
\text { aligned to the applied position but has a graduate } \\
\text { degree that is aligned to the position }\end{array}$ & 10 \\
\hline Highly Aligned & $51-99$ & $\begin{array}{c}\text { The applicant has a bachelor's degree is aligned } \\
\text { and pursing a graduate degree that is also aligned } \\
\text { to the applied position }\end{array}$ & $11-19$ \\
\cline { 2 - 5 } & 100 & $\begin{array}{c}\text { Completed the bachelor's degree and at least a } \\
\text { master's degree that are both aligned to the } \\
\text { applied position }\end{array}$ & 20 \\
\hline
\end{tabular}

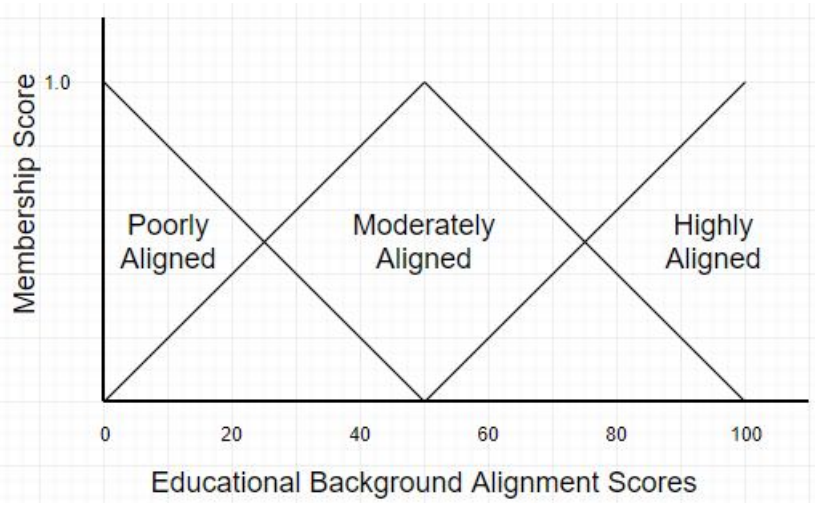

Figure 6: Membership Function for the Educational Background Alignment

The alignment of the applicant's educational background to the position being applied for normally depends on the nature of the job position. Figure 6 shows the membership function for the alignment of the educational background while Figure 7 illustrates the membership function for professional qualifications. Table 2 above illustrates the suggested scoring system by assigning alignment scores for each educational background. Additionally, the job grade points column reflected in Table 2 will be utilized for assigning the appropriate pay and incentive structure of 
employees that gives weight on the next stage of the researchers' article on compensation and benefits. Meanwhile, Table 3 shows the score reference for the educational background of the applicant.

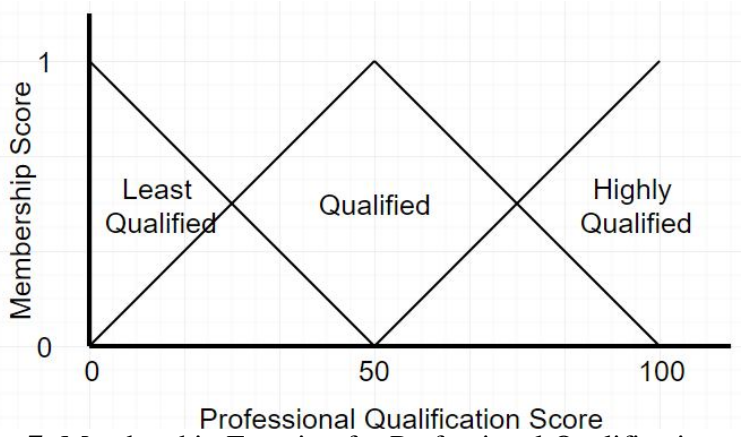

Fig. 7: Membership Function for Professional Qualifications

Table 3: Score Reference for the Educational Background of the

\begin{tabular}{|c|c|c|}
\hline \multicolumn{2}{|c}{ Professional } \\
$\begin{array}{c}\text { Qualification } \\
\text { /Certification }\end{array}$ & Score & Details \\
\hline $\begin{array}{c}\text { No } \\
\text { certification }\end{array}$ & 25 & No license or certification \\
\hline Certified & 50 & $\begin{array}{c}\text { Gained certification from } \\
\text { recognized from government } \\
\text { or professional institution }\end{array}$ \\
\hline $\begin{array}{c}\text { Professional } \\
\text { License }\end{array}$ & $51-99$ & $\begin{array}{r}\text { Currently has multiple } \\
\text { certifications } \\
\text { 10 points for every } \\
\text { certification }\end{array}$ \\
\cline { 2 - 4 } & 100 & $\begin{array}{r}\text { Holder of professional } \\
\text { license }\end{array}$ \\
\hline
\end{tabular}

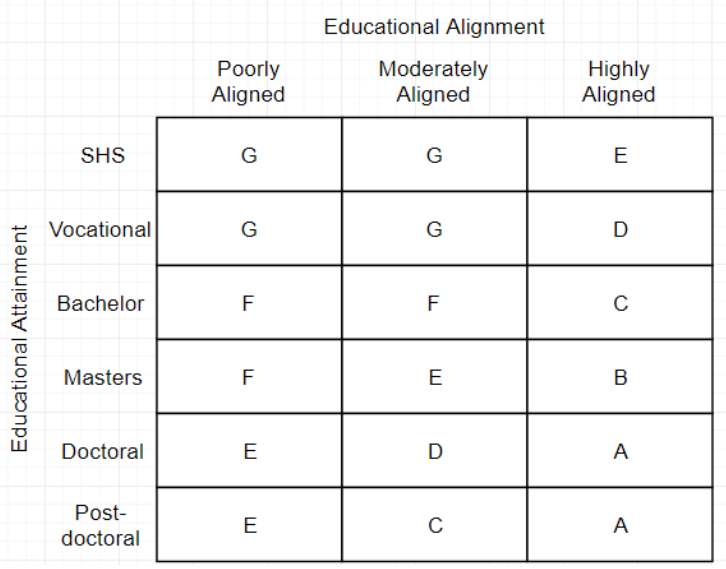

Fig. 8: Fuzzy Associative Matrix for Highly Educated Profile

\subsection{Fuzzy Logic Inference System for Highly Skilled Area Rating}

This section is used to quantify the skills and competence of the applicants. The output of this algorithm s called the Highly Skilled rating. This profile considers the alignment of the skills of the applicant to the nature of the job position being offered. The structure of the fuzzy logic for this profile is shown in Figure 8.

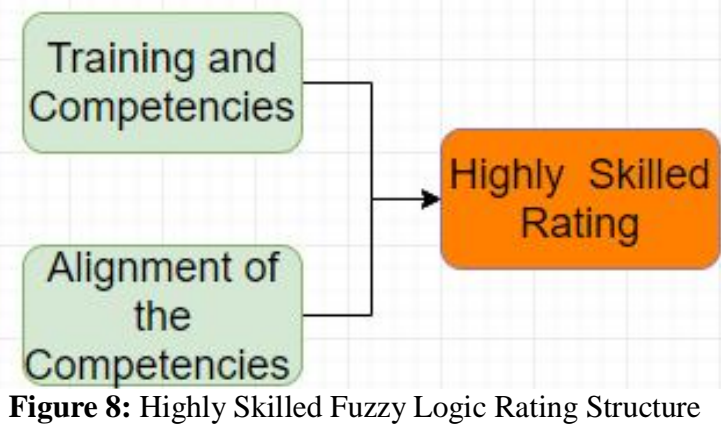

Figure 8 considers work experience that equates to the specific job position being applied for. There are instances that an applicant may have impressive work experience but is totally or insufficiently aligned to the job. For instance, an employee has gained remarkable technical experience in an industry for a number of years but will decide on a career change to expand his or her horizons in a totally new field for example in the academe. Therefore, the fuzzy inference system balances the inconsistency to form a logical control criteria of employee selection in the organization to determine the best fit employee.

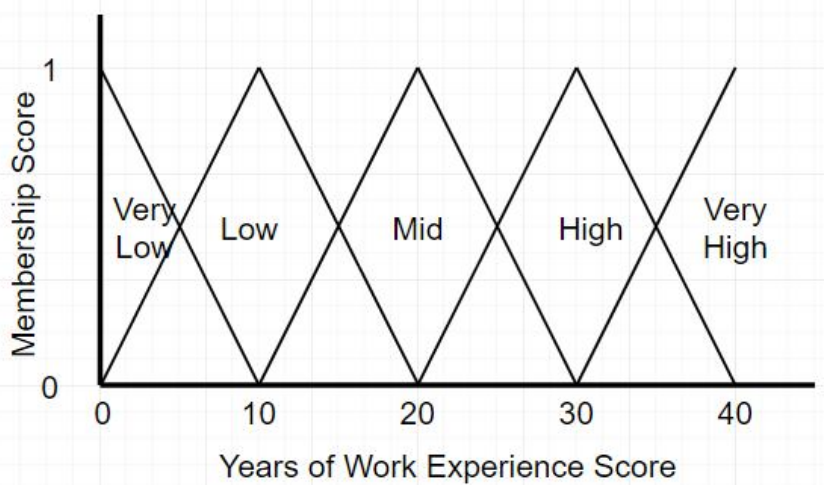

Fig. 9: Membership function for the Number of Years of Experience

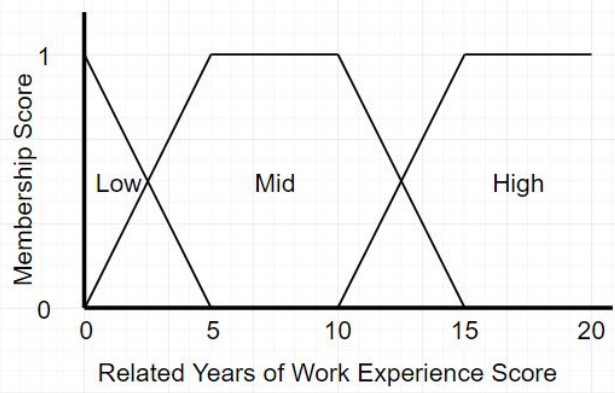

Fig. 10: Membership Function for the Years of Experience related to the Position

Figure 9 and Figure 10 show the membership functions of the number of years of experience of the applicant as well as the number of years of experience related to the vacant job position. This will give better view on the skills on the applicant that can determine the degree of fitness of the applicant to the job position. 


\section{DISCUSSION OF RESULTS}

In order to demonstrate the effectiveness of the proposed algorithm, let us consider the profiles of the applicants shown in Table 4 below. When candidates apply for a particular engineering management position, a professional certification or license may not be a requirement. However, educational alignment is given importance and an experience requirement of at least senior level is preferred.

For accuracy purposes, the results of this fuzzy-based profiling system was compared to the manual applicant ranking based from the selection viewpoint of an HR practitioner that revealed ratings that differ.

In Table 5, the applicants were scored differently according to a criterion that received different ranking scores. This manual selection process is not only tedious for HR especially when sorting through large volumes of applications but objective applicant alignment assessment would be difficult with criteria that are almost related.
Results in the proposed intelligent algorithm in Table 6 revealed that applicant credentials were aligned to the preferential attributes and then ranked accordingly. If the ranking scores will be equivalent in the highly educated attribute, then the highly skilled scores will be the final consideration. Also, these preferential attributes can be adjusted accordingly by the HR or requesting department.

Although, the results in the proposed shortlist algorithm in the highly skilled rank column in Table 6 received the same ranking with the manual score according to professional qualification column in Table 5, the integral contribution of this article is to provide an efficient system that predicts and filters mechanisms to measure a candidate's alignment to a specific job post, predicting their possible future performance by ranking each individual candidate in real time. This ensures organizations are effective in their outcome-focused hiring of employees as candidates are judged based on their credentials and scored accordingly on how well they fit the criteria.

Table 4: Sample Information Sheet of Job Applicants

\begin{tabular}{|c|c|c|c|c|c|c|c|}
\hline \multirow{2}{*}{ 竭 } & \multirow{2}{*}{ 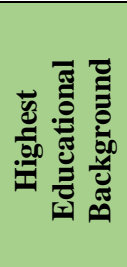 } & \multicolumn{3}{|c|}{ Field of Specialization } & \multirow{2}{*}{ 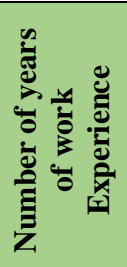 } & \multirow{2}{*}{ 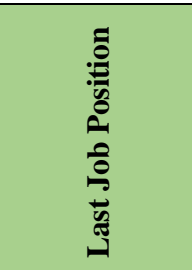 } & \multirow{2}{*}{ 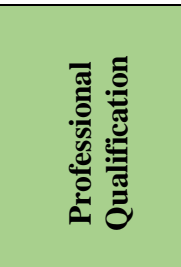 } \\
\hline & & $\frac{\grave{c}}{\frac{\mathscr{e}}{\tilde{e}}}$ & 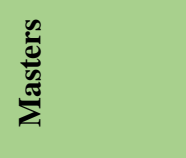 & 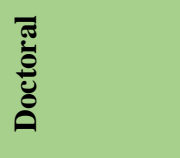 & & & \\
\hline $\mathbf{A}$ & $\begin{array}{c}\text { Doctoral } \\
\text { degree }\end{array}$ & Engineering & Engineering & Engineering & 10 years & $\begin{array}{l}\text { Senior level } \\
\text { for } 7 \text { years }\end{array}$ & $\begin{array}{c}\text { With } \\
\text { Professional } \\
\text { License }\end{array}$ \\
\hline B & $\begin{array}{c}\text { Bachelor } \\
\text { degree }\end{array}$ & Management & NA & $\mathrm{NA}$ & 20 years & $\begin{array}{l}\text { Director for } 2 \\
\text { years, (senior } \\
\text { for } 7 \text { years) }\end{array}$ & $\begin{array}{c}\text { With } 2 \\
\text { Certifications }\end{array}$ \\
\hline $\mathbf{C}$ & $\begin{array}{c}\text { Master's } \\
\text { degree }\end{array}$ & $\begin{array}{l}\text { Arts and } \\
\text { Sciences }\end{array}$ & Management & $\mathrm{NA}$ & 5 years & $\begin{array}{l}\text { Entry level } \\
\text { for } 3 \text { years }\end{array}$ & $\begin{array}{c}\text { With } \\
\text { certification }\end{array}$ \\
\hline D & $\begin{array}{c}\text { Post- } \\
\text { Doctoral } \\
\text { degree }\end{array}$ & Engineering & Management & Management & 21 years & $\begin{array}{l}\text { Executive for } \\
2 \text { years, } \\
\text { (director for } 5 \\
\text { years, senior } \\
\text { for } 5 \text { years) }\end{array}$ & $\begin{array}{l}\text { No license or } \\
\text { certification }\end{array}$ \\
\hline $\mathbf{E}$ & $\begin{array}{c}\text { Bachelor } \\
\text { degree }\end{array}$ & Engineering & NA & NA & 18 years & $\begin{array}{c}\text { Junior Level } \\
\text { for } 3 \text { years }\end{array}$ & $\begin{array}{c}\text { No license or } \\
\text { certification }\end{array}$ \\
\hline
\end{tabular}

Table 5: Manual Applicant Ranking According to Different Criteria

\begin{tabular}{|c|c|c|c|c|}
\hline Applicants & $\begin{array}{c}\text { Rank According } \\
\text { to Educational } \\
\text { Attainment }\end{array}$ & $\begin{array}{c}\text { Rank According to } \\
\text { Professional } \\
\text { Qualifications }\end{array}$ & $\begin{array}{c}\text { Rank According to } \\
\text { Training and } \\
\text { Competencies }\end{array}$ & $\begin{array}{c}\text { Rank According to } \\
\text { years of experience } \\
\text { related to job } \\
\text { position }\end{array}$ \\
\hline A & 2 & 3 & 4 & 4 \\
\hline B & 4 & 2 & 3 & 3 \\
\hline C & 3 & 5 & 5 & 5 \\
\hline D & 1 & 1 & 2 & 2 \\
\hline E & 5 & 4 & 1 & 1 \\
\hline
\end{tabular}


Table 6: Applicant Profiles based on the Proposed Algorithm

\begin{tabular}{|c|c|c|c|c|c|c|c|c|}
\hline Applicants & $\begin{array}{c}\text { Educational } \\
\text { Background } \\
\text { Score }\end{array}$ & $\begin{array}{c}\text { Alignment } \\
\text { Score }\end{array}$ & $\begin{array}{c}\text { Highly } \\
\text { Educated } \\
\text { Score }\end{array}$ & Rank & $\begin{array}{c}\text { Years of } \\
\text { Experience }\end{array}$ & $\begin{array}{c}\text { Years of } \\
\text { related } \\
\text { Experience }\end{array}$ & $\begin{array}{c}\text { Highly } \\
\text { Skilled } \\
\text { Score }\end{array}$ & Rank \\
\hline A & 80 & 100 & 100 & 1 & 10 & 7 & 85 & 3 \\
\hline B & 40 & 50 & 50 & 3 & 20 & 9 & 90 & 2 \\
\hline C & 60 & 50 & 60 & 2 & 5 & 0 & 72.5 & 5 \\
\hline D & 100 & 100 & 100 & 1 & 21 & 12 & 92.32 & 1 \\
\hline E & 40 & 50 & 50 & 3 & 18 & 0 & 79 & 4 \\
\hline
\end{tabular}

\section{CONCLUSION}

The results indicate that the proposed fuzzy-based intelligent profiling system further streamlines the talent acquisition process in the hiring and selection stage by fine tuning it with profiling variables, specifically, the highly educated and highly skilled attributes.

This profiling system provides a basis to HR and requesting departments to shortlist candidates that are best suited to their needs while providing a balanced yet objective and systematic method of selecting applicants from a large pool with preferential criteria that may be related and could be interpreted differently by the evaluator.

Artificial intelligence is a transformative force in the business environment as it greatly assists HR managers and decision makers to select candidates in real time. This intelligent system eradicates manual selection from huge candidate profiles as this automatically shortlists and allows HR to accurately screen applicants. This modified fuzzybased system creates a more equitable hiring and selection process for organizations as it determines the best fit candidates according to its needs.

\section{REFERENCES}

[1] Kumar, A.S. "Ensemble Online Sequential Extreme Learning Machine and Swarm Intelligent Based Feature Selection for Cleveland Heart Disease Prediction System". International Journal of Advanced Trends in Computer Science \& Engineering, Vol. 6.5, pp. 84- 91, 2017.

[2] Golec, A., \& Kahya, E. "A fuzzy model for competency-based employee evaluation and selection". Computers \& Industrial Engineering, Vol. 52.1, pp. 143-161, 2007.

https://doi.org/10.1016/j.cie.2006.11.004

[3] Selvapriya, R. "A Novel Approach for Semi Supervised Clustering Algorithm". International Journal of Advanced Trends in Computer Science \& Engineering, Vol. 6.2, pp. 14- 17, 2017.

[4] Macwan, N., \& Sajja, P. S. "Performance appraisal using fuzzy evaluation methodology". International Journal of Engineering and Innovative Technology, Vol. 3.3, pp. 324-329, 2013.

[5] Manoj, B., Sasikanth, K.V.K., Subbarao, M.V., \& Prakash, V Jyothi. "Analysis of Data Science with the use of Big Data". International Journal of Advanced Trends in Computer Science \& Engineering, Vol. 7.6, pp. 87- 90, 2018. https://doi.org/10.30534/ijatcse/2018/02762018

[6] Escolar-Jimenez, C., Matsuzaki, K., \& Gustilo, R. "Fuzzy-based Intelligent Shortlisting Process for Human Resource Job Recruitment Procedures". International Journal of Engineering and Technology, Vol. 7, pp. 229-233, 2018.

[7] Villanueva, L., \& Gustilo, R. "Artificial Neural Network Based Antenna Sensitivity Assignments for Chaotic Internet Service Provider Network Architecture". International Journal of Engineering and Technology, Vol. 7,2.3 pp. 14-17, 2018. https://doi.org/10.14419/ijet.v7i2.3.9958

[8] Gustilo, R.C. "Design of Wireless Disaster Alarm System Using Microwave Links". Journal of Telecommunication, Electronic and Computer Engineering (JTEC), Vol. 10.1.6, pp.103-108. 2018. 